\title{
Effects of Intercropping Faba Bean on Onion and Wheat With or Without Inoculated Bacteria on Yields of the Three Crops
}

\author{
M.A. Abou-Keriasha, Nadia M.A. Eisa and N.M.H. El-Wakil \\ Crop Intensification Research Department, Field Crops \\ Research Institute, A.R.C., Giza, Egypt.
}

\begin{abstract}
TWO FIELD experiments were carried out at Mallawi Agric. Res. St. (Middle Egypt) during the two seasons of 2011/2012 and 2012/2013 to study the effect of intercropping faba bean on two crops (onion and wheat) and inoculated with bacteria on the yield and its components. A randomized complete block design in a split plot arrangement with three replications was used in both seasons. The main plots were devoted to the cropping systems, while the sub-plots were allocated for two treatments of co-inoculated.
\end{abstract}

The results showed that plant height, yield and yield components of the three crops (faba bean, onion and wheat) were decreased under intercropping condition. The plant height of intercropped faba bean on wheat was more effect $17.5 \mathrm{~cm}$ shorter but with onion was $5.1 \mathrm{~cm}$ shorter than sole. The most yield components of intercropped faba bean (no. of branches/plant, plants $/ \mathrm{m}^{2}$, pods/plant, seeds/pod and seed yield/plant) were decreased which resulted in decreased seed and straw yield/fad. The reduction in seed and straw yield/fad of faba bean were estimated by 32.0 and $7.5 \%$ when intercropping on onion and by 68.5 and $36.4 \%$ when intercropping on wheat, respectively, compared to solid.

The results show also that seed inoculation with bacteria increased plant height, no. of branches/plant, no. of plants $/ \mathrm{m}^{2}$, no. of seeds $/$ pod, wt. of 100 seed, and seed and straw yield as compared with uninoculation seeds. The increased in seed and straw yields/fad was 14.0 and $5.7 \%$ as compared with uninoculation, respectively. The yield and yield components of intercropped crops (onion and wheat) were decreased when intercropping with faba bean. The reduction in bulb yield of onion was 3.0 and $4.4 \%$, while the reduction in wheat yield was 7.8 and $9.3 \%$ with or without inoculated faba bean seeds, respectively. The highest values of land equivalent ratio "LER" (1.59) and monetary advantage index 'MAI' (3636.477) were observed when inoculation faba bean seeds before sown and intercropping on onion. While, the values of competitive ratio (CR) of faba bean were greater when intercropping on onion than those intercropping on wheat.

Keywords: Intercropping, Inoculation, Faba bean, Onion, Wheat. 
Faba bean (Vicia faba L.) is grown world-wide as protein source for food and feed, but at the same time faba bean offers ecosystem services such as renewable inputs of nitrogen $(\mathrm{N})$ into crops and soil vie biological $\mathrm{N}_{2}$ fixation and a diversification of cropping systems. At present, cultivated faba bean area in Egypt at average of (97906) faddan with total annual production is (140000) tons which is not enough (Agricultural Statistics, 2013). The reduction in cultivated faba bean area is due to the increasing in cultivated the other winter crops area especial wheat, berseem, sugar beet, .....etc. Therefore, efforts are focused to increase its productivity to fill the gap between the local production and human consumption through many factors as cropping systems, cultivar selection, diseases and weeds control. The cropping systems are included crop rotation, relay intercropping and intercropping with other crops and fertilizer.

Past studies of faba bean in cropping systems have tended to focus on the effect of faba bean as a pre-crop in mainly cereal intensive rotations, whereas similar information on the effect of preceding crops on faba bean is lacking.

Most faba bean crops in the industrialized countries are sole cropped, but in other parts of the world (Asia and Africa) intercropping of faba bean with other cereals is a common practice (Zhang et al., 2004). Intercropping can improve the use of resources (land, nutrients, especially soil nitrogen, light, water) by $10-50 \%$ above sole crop grown on the same piece of land expressed in Land Equivalent Ratio (LER) (Willey, 1979). The advantages of intercropping are derived from the competitive interference principle (Vandermeer, 1989), in which the interspecific competition between intercrop component species will be less than intraspecific competition in sole crops. This is based on different growth patterns, more efficient interception of light and used of water and nutrients over growing seasons (Willey, 1979). Yield advantages have been recorded in many legumecereal intercropping systems, included soybean-sorghum (Ghosh et al., 2009), cowpea-maize (Abou-keriasha et al., 2011), faba bean-wheat (Abou-Keriasha et al., 2008) and vetch-oat (Tuna \& Orak, 2007). In Egypt, intercropping faba bean on other winter crops (wheat, onion, sugar beet, sugar cane and tomato) is assistant in increased cultivars faba bean area and reduced the gap.

Martin \& Snaydon (1982) showed that grain yield of faba bean was increased from 37 to $51 \%$ (without fertilizer $\mathrm{N}$ ) and 22 to $38 \%$ (with $50 \mathrm{~kg} \mathrm{~N}^{-1}$ ), when the row design was changes from mixed in the same row to alternating double rows, respectively. Liben et al. (2001) and Eskandari \& Ghanbart (2010) showed that grain yield, harvest index and thousands grain weight of wheat or maize were reduced in intercropping, while in bean decreased only in grain yield. The highest land equivalent ratio (LER) and economic advantage with a net return were observed in treatment one row maize : one row faba bean.

Fen et al. (2006) and Abou-Keriasha et al. (2008) showed that number of branches, number of seeds/pod, wt. of 100 seeds, grain yield/plant and grain yield/fad were decreased when intercropping with wheat. The competitive ratio (CR) of wheat was greater than for common faba bean indicating the dominance

Egypt. J. Agron. 35, No. 2 (2013) 
of wheat under those crop mixtures. It's due to the density of wheat was higher than faba bean.

Faba beans forms a symbiotic relationship with the soil bacteria Rhizobium leguminossaram br Vicia and with fungi Arbuscular mycorrhizae was investigated. When faba beans are inoculated on soils containing indigenous populations the inoculants strain may be responsible for a large proportion of the nodules (Carter et al., 1994). Khosravi \& Ramezanpour (2004) and Alipour et al. (2013) observed that faba bean seed inoculation with bacteria before sowing had a positive and significant effect on plant height, grain weight, grain filling of pods, number of pods, length and width of pods, reduction of flowers fall and traits associated with yield and yield components.

Radwan et al. (2007), Dashadi et al. (2011), Rugheim \& Abdelgani (2012) and Mohamed \& Babiker (2012) showed that co-inoculation with Rhizobium and Azotobacter increased seed yield and biological yield. The present study was carried out in order to investigate the effects of intercropping faba bean on the other crops and Rhizobium inoculation on yield and yield components of faba bean.

\section{Materials and Methods}

The rotation trials were stated since 2008/09 at Mallawi Agric. Res. Sta. (Middle Egypt). The objective of this study is to comparisons different three rotations under intercropping condition. The three forms crops rotations are shown:

\section{Prevailing}

Year

\begin{tabular}{|l|c|}
\hline 1 & $\begin{array}{c}\text { Wheat } \\
\text { then } \\
\text { maize }\end{array}$ \\
\cline { 2 - 2 } & $\begin{array}{c}\text { Faba bean } \\
\text { then } \\
\text { maize }\end{array}$ \\
\cline { 2 - 2 } 3 & $\begin{array}{c}\text { Onion } \\
\text { then } \\
\text { soybean }\end{array}$ \\
\hline
\end{tabular}

\section{Propose I}

\begin{tabular}{|c|}
\hline Wheat + faba \\
bean then \\
maize + \\
cowpea \\
\hline Faba bean \\
then \\
maize \\
\hline Onion \\
then \\
soybean \\
\hline
\end{tabular}

\section{Propose II}

\begin{tabular}{|c|}
\hline $\begin{array}{c}\text { Clover/wheat }+ \\
\text { faba bean } \\
\text { then } \\
\text { maize }+ \text { soybean }\end{array}$ \\
\hline Clover \\
then \\
maize + cowpea \\
\hline Faba bean + \\
onion \\
then \\
soybean \\
\hline
\end{tabular}

Faba bean crop was grown during the two seasons, 2011/2012 and 2012/2013 (after first cycle of rotations) was used inoculated bacteria as the second factor with the intercropping system to study effect of intercropping faba bean on two crops (onion and wheat) and inoculated with bacteria on faba bean productivity. 
A randomized complete block design (RCBD) in a split-plot with three replications was used in both seasons. The main plots were devoted to the three cropping systems as following:

1. Solid faba bean (C.V 843) was sown four rows/on the top bed in hills, $20 \mathrm{~cm}$ between and two plants/hill (100\%).

2. Faba bean + onion (intercrop): One faba bean row was sown on each side of all ridges, while onion four rows were transplanted on the top of all ridges, $20 \mathrm{~cm}$ between and $10 \mathrm{~cm}(50 \%+100 \%)$.

3. Faba bean + wheat (intercrop): One faba bean row was sown on each side of all ridges and four wheat rows were sown on top of ridges $20 \mathrm{~cm}$ apart and $20 \mathrm{~cm}$ between hills $(50 \%+100 \%)$.

While the sub plots were allocated for two fertilizer treatments (inoculated seeds with bacteria or uninoculated). Addition solid of intercropped crops (wheat and onion) for comparison and estimated complete relationship and yield advantages. The sub-plot size was $17.5 \mathrm{~m}^{2}\left({ }^{1} / 240 \mathrm{fad}\right)$ containing 5 width ridges, each of $3.5 \mathrm{~m}$ in length and $1.0 \mathrm{~m}$ in width.

Faba bean seeds was mixed with Rhizobium and Azotobacter (inoculated) used in the study was obtained from the Agricultural Microbiology Department, Soils, Water and Environment Research Institute, ARC, Giza. Before, inoculation the seeds surface was mixed with $15 \%$ sugar completely for more adhesion of inoculums.

Sowing of faba bean, wheat seeds and transplanting onion were during the first week of November in the two seasons. Normal cultural practices were done for crops (faba bean, onion and wheat) as recommended. Addition of nitrogen fertilizer at rate 70 and $80 \mathrm{~kg} \mathrm{~N} /$ fad for wheat and onion, respectively, in form of ammonium nitrate $(33.5 \%)$ with three dose equals, while calcium superphosphate $\left(15 \% \mathrm{~kg} \mathrm{P}_{2} \mathrm{O}_{5} / \mathrm{fad}\right)$ at rate of $30 \mathrm{~kg} \mathrm{P}_{2} \mathrm{O}_{5} / \mathrm{fad}$ and potassium sulfate $\left(48 \% \mathrm{~K}_{2} \mathrm{O}\right)$ at rate of $24 \mathrm{~kg} \mathrm{~K}_{2} \mathrm{O} /$ fad were added during soil preparation.

At maturity, ten plants of faba bean, wheat and onion were randomly taken from each sub plot to determine plant characters and yield components. Each sub plot was harvested (seeds, grains or bulbs) were separated through sifting. Yield of all crops were determined on plot basis and converted to one faddan. The following studied characters of the crops were done :

Faba bean were studied: Plant height, no. of branches/plant, no. of plants $/ \mathrm{m}^{2}$, pod length, no. of seeds/pod, weight of seeds/plant, no of. pods/plant, weight of 100 seeds, seed yield/fad and straw yield/fad.

Onion: Leave long, bulb diameter, weight of bulb and yield bulb/fad.

Wheat: Plant height, no. of spike $/ \mathrm{m}^{2}$ and grain yield/fad.

Egypt. J. Agron. 35, No. 2 (2013) 


\section{Competitive relationship and yield advantage}

Land equivalent ratio (LER)

LER defined as the ratio of area needed under sole cropping to one of intercropping at the same management level to produce an equivalent yield (Willey, 1979). It is calculated as follows:

$$
\begin{array}{ccc}
\operatorname{LER}=\left(\mathrm{Y}_{\mathrm{ab}} / \mathrm{Y}_{\mathrm{a} a}\right) & +\left(\mathrm{Y}_{\mathrm{ba}} / \mathrm{Y}_{\mathrm{bb}}\right) \\
\text { where } & \mathrm{Y}_{\mathrm{aa}}=\text { Pure stand yield of crop a } & \mathrm{Y}_{\mathrm{bb}}=\text { Pure stand yield of crop } \mathrm{b} \\
\mathrm{Y}_{\mathrm{ab}}=\text { Intercrop yield of crop a } & \mathrm{Y}_{\mathrm{ba}}=\text { Intercrop yield of crop } \mathrm{b}
\end{array}
$$

Competitive ratio $(C R)$

$\mathrm{CR}$ indicates the number of times by which one component crop is more competitive than the other. Relative species competition is often evaluated using competitive ratios (Willey \& Rao, 1980). It is calculated as follows:

$$
\mathrm{R}_{\mathrm{a}}=\left(\mathrm{L}_{\mathrm{a}} / \mathrm{L}_{\mathrm{b}}\right) \mathrm{x}\left(\mathrm{Z}_{\mathrm{ba}} / \mathrm{Z}_{\mathrm{ab}}\right) \quad \mathrm{R}_{\mathrm{b}}=\left(\mathrm{L}_{\mathrm{b}} / \mathrm{L}_{\mathrm{a}}\right) \times\left(\mathrm{Z}_{\mathrm{ab}} / \mathrm{Z}_{\mathrm{ba}}\right)
$$

where $R_{a}=$ The competitive ratio of crop a $R_{b}=$ The competitive ratio of crop $b$

$$
\mathrm{L}_{\mathrm{a}}=\text { LER of crop a } \quad \mathrm{L}_{\mathrm{b}}=\text { LER of crop } \mathrm{b}
$$

$Z_{a b}=$ The respective proportion of crop $a$ in the intercropping system

$Z_{b a}=$ The respective proportion of crop $b$ in the intercropping system

Monetary advantage index (MAI)

Suggests that the economic assessment should be in terms of the value of land saved, this could probably be most assessed on the basis of the rentabe of this land. MAI was calculated according to the formula, suggested by Willey (1979) :

Value of combined intercrops $x($ LER - 1)

$$
\text { MAI = }
$$

\section{LER}

Price of crops was calculated in Egyptian pound 400 L.E./ardab wheat, 500 L.E./ardab faba bean, 500 L.E./ton onion, 280 L.E./ton straw of wheat or faba bean. All data of the two seasons and the combined of the data were statistically analyzed according to Snedecor \& Cochran (1988) using MSTAT software Computer V4 (1980). L.S.D. test at $5 \%$ level was used to compare between treatments.

\section{Faba bean}

\section{Results and Discussion}

Effect of intercropping

The data obtained on the effect of intercropping on plant height, yield and yield components are presented in Table 1. The data showed significant differences in all studied characters due to intercropping faba bean on onion or wheat except plant height, number of pods/plant, number of seeds/pod and pod length in the first season and number of seeds/pod in the combined analysis. The results clearly show that intercropping system resulted in shorter faba bean plants than solid planting. The plant height of intercropped faba bean on wheat was more effect $17.5 \mathrm{~cm}$ shorter than sole, while intercropped faba bean on onion was less effect $5.1 \mathrm{~cm}$ shorter than sole (combined analysis). This short in intercropped faba bean plants might due to more shading effect of intercropped crops density and adverse low of the intercepted light competition for nutrients, 
carbon dioxide might have had reflect adverse effect on growth of faba bean especial when intercropping on wheat. Similar results were observed by Ghosh et al. (2009) and Abou-Keriasha et al. (2011).

TABLE 1. Effect of cropping systems on yield and yield components of faba bean during the first, second and combined analysis of two seasons.

\begin{tabular}{|c|c|c|c|c|c|c|c|c|c|c|}
\hline \multirow[t]{2}{*}{ Traits } & \multirow{2}{*}{$\begin{array}{c}\text { Plant } \\
\text { height } \\
\text { (cm) }\end{array}$} & \multicolumn{3}{|c|}{ No. of } & \multirow{2}{*}{$\begin{array}{c}\text { Pod } \\
\text { length } \\
(\mathrm{cm})\end{array}$} & \multirow{2}{*}{$\begin{array}{c}\text { No. of } \\
\text { seeds/ } \\
\text { pod }\end{array}$} & \multirow{2}{*}{$\begin{array}{c}\text { Wt. of } \\
\text { seeds/ } \\
\text { plant (g) }\end{array}$} & \multirow{2}{*}{$\begin{array}{l}\text { Wt. of } \\
100 \\
\text { seeds } \\
(g) \\
\end{array}$} & \multicolumn{2}{|c|}{ Yield / fad } \\
\hline & & $\begin{array}{c}\text { branches/ } \\
\text { plant }\end{array}$ & $\begin{array}{c}\text { plants/ } \\
\mathbf{m}^{2}\end{array}$ & $\begin{array}{l}\text { pods/ } \\
\text { plant }\end{array}$ & & & & & $\begin{array}{c}\text { Seed } \\
(\text { ardab) }\end{array}$ & $\begin{array}{c}\text { Straw } \\
\text { (ton) }\end{array}$ \\
\hline \multicolumn{11}{|c|}{ First season } \\
\hline $\mathbf{A 1}$ & 139.50 & 2.65 & 29.42 & 9.06 & 10.00 & 3.25 & 181.83 & 80.65 & 8.30 & 3.93 \\
\hline A2 & 138.30 & 2.00 & 14.26 & 7.83 & 9.55 & 3.31 & 113.83 & 85.83 & 5.40 & 3.56 \\
\hline A3 & 125.10 & 1.33 & 12.80 & 6.11 & 8.41 & 3.13 & 106.83 & 61.16 & 2.60 & 2.61 \\
\hline $\begin{array}{l}\text { L.S.D. } \\
0.05\end{array}$ & N.S. & 0.19 & 1.2 & N.S. & N.S. & N.S. & 20.6 & 11.6 & 1.2 & 0.51 \\
\hline \multicolumn{11}{|c|}{ Second season } \\
\hline A1 & 142.50 & 2.23 & 29.25 & 7.48 & 9.43 & 3.55 & 179.00 & 69.83 & 8.20 & 4.10 \\
\hline A2 & 133.50 & 2.15 & 14.36 & 7.26 & 9.90 & 3.11 & 100.66 & 82.33 & 4.70 & 3.81 \\
\hline A3 & 122.00 & 1.25 & 12.90 & 6.33 & 8.30 & 3.03 & 86.50 & 61.66 & 2.60 & 2.51 \\
\hline $\begin{array}{l}\text { L.S.D. } \\
0.05 \\
\end{array}$ & 4.7 & 0.45 & 0.6 & 0.83 & 0.57 & 0.31 & 14.7 & 5.8 & 0.73 & 0.14 \\
\hline \multicolumn{11}{|c|}{ Combined of the two seasons } \\
\hline $\mathbf{A 1}$ & 141.00 & 2.40 & 29.36 & 8.30 & 9.70 & 3.40 & 180.40 & 75.20 & 8.20 & 4.01 \\
\hline $\mathbf{A 2}$ & 135.90 & 2.10 & 14.36 & 7.50 & 9.70 & 3.20 & 107.20 & 84.10 & 5.60 & 3.71 \\
\hline A3 & 123.50 & 1.30 & 12.90 & 6.20 & 8.30 & 3.10 & 96.60 & 61.40 & 2.60 & 2.55 \\
\hline $\begin{array}{l}\text { L.S.D. } \\
0.05 \\
\end{array}$ & 9.5 & 0.22 & 0.8 & 1.29 & 0.55 & N.S. & 14.9 & 3.8 & 0.46 & 0.34 \\
\hline
\end{tabular}

A1: Faba bean solid

A2: Faba bean + onion intercrop

A3: Faba bean + wheat intercrop

The highest values of yield and yield components were observed in solid planting except weight of 100 seeds which is higher when intercropping with onion in both seasons and the combined analysis. The reduction in yield components of faba bean were 12.5 and $45.8 \%$ for number of branches/plant, 51.1 and $56.1 \%$ for number of plants $/ \mathrm{m}^{2}, 0.0$ and $14.4 \%$ for pod length, 9.6 and $25.3 \%$ for number of pods/plant, 5.9 and $8.8 \%$ for number of seeds/pod and 40.6 and $46.5 \%$ for weight of seeds/plant when intercropping on onion and wheat, respectively (combined analysis).

On the contrary, seed and straw yield/fad were decreased by 32.0 and $7.5 \%$ when intercropped on onion and by 68.5 and $36.4 \%$ when intercropped on wheat, respectively, compared to solid planting. This decreasing in grain yield due to decreases of number of spikes $/ \mathrm{m}^{2}$ (50\% solid planting) as well as the decreases of number of pods/plant and seeds/pod and weight of seeds/plant under intercropping condition compared to solid planting. Similar results are in agreement with those obtained by Liben et al. (2001), Fen et al. (2006) and Abou-Keriasha et al. (2008).

Egypt. J. Agron. 35, No. 2 (2013) 


\section{The effect of inoculation}

Data in Table 2 showed that inoculation faba bean seeds with Azotobacter had not significant effect on all studied characters of faba bean except plant height, number of branches/plant, seed yield/fad in the two seasons and their combined analysis and number of seeds/pod and straw yield/fad in the second season and the combined analysis, respectively. The not significant effect may be due to that soil site of experiment is contain large population of indigenous Rhizobia and Mycorrhiza for faba bean and inoculation is usually not required, particularly if the land had previously been sown to faba bean (Murinda \& Saxena, 1985). However, the highest values of the plant height, number of branches/plant, number of plants $/ \mathrm{m}^{2}$, number of seeds/pod, weight of 100 seed, seed and straw yield/fad were observed when inoculation of faba bean seed, while length and weight of seeds/plant were higher in uninoculated. Similar results were observed by Khosvavi \&Ramezanpour (2004).

TABLE 2 . Effect of inoculation on yield and yield components of faba bean during the first, second and combined analysis of two seasons.

\begin{tabular}{|c|c|c|c|c|c|c|c|c|c|c|}
\hline \multirow[t]{2}{*}{ Traits } & \multirow{2}{*}{$\begin{array}{c}\text { Plant } \\
\text { height } \\
(\mathrm{cm})\end{array}$} & \multicolumn{3}{|c|}{ No. of } & \multirow{2}{*}{$\begin{array}{c}\text { Pod } \\
\text { length } \\
(\mathrm{cm})\end{array}$} & \multirow{2}{*}{$\begin{array}{c}\text { No. of } \\
\text { seeds/ } \\
\text { pod }\end{array}$} & \multirow{2}{*}{$\begin{array}{c}\text { Wt. of } \\
\text { seeds/ } \\
\text { plant (g) }\end{array}$} & \multirow{2}{*}{$\begin{array}{l}\text { Wt. of } \\
100 \\
\text { seeds } \\
\text { (g) }\end{array}$} & \multicolumn{2}{|c|}{ Yield / fad } \\
\hline & & $\begin{array}{c}\text { branches/ } \\
\text { plant }\end{array}$ & $\begin{array}{c}\text { plants/ } \\
\mathbf{m}^{2}\end{array}$ & $\begin{array}{l}\text { pods/ } \\
\text { plant }\end{array}$ & & & & & $\begin{array}{c}\text { Seed } \\
(\text { ardab) }\end{array}$ & $\begin{array}{c}\text { Straw } \\
\text { (ton) }\end{array}$ \\
\hline \multicolumn{11}{|c|}{ First season } \\
\hline B1 & 137.40 & 2.06 & 19.40 & 7.97 & 9.25 & 3.16 & 128.88 & 78.06 & 5.90 & 3.51 \\
\hline B2 & 131.20 & 1.92 & 18.27 & 7.36 & 9.40 & 3.30 & 139.44 & 73.70 & 4.90 & 3.22 \\
\hline $\begin{array}{l}\text { L.S.D. } \\
0.05\end{array}$ & 6.0 & 0.4 & N.S. & N.S. & N.S. & N.S. & N.S. & N.S. & 0.55 & N.S. \\
\hline \multicolumn{11}{|c|}{ Second season } \\
\hline B1 & 136.00 & 1.92 & 19.23 & 6.72 & 9.17 & 3.36 & 119.44 & 71.11 & 5.50 & 3.50 \\
\hline B2 & 129.30 & 1.83 & 18.50 & 7.33 & 9.24 & 3.10 & 124.66 & 71.44 & 4.80 & 3.40 \\
\hline $\begin{array}{l}\text { L.S.D. } \\
0.05\end{array}$ & 3.2 & 0.47 & N.S. & N.S. & N.S. & 0.17 & N.S. & N.S. & 0.30 & N.S. \\
\hline \multicolumn{11}{|c|}{ Combined of the two seasons } \\
\hline B1 & 136.20 & 2.00 & 19.31 & 7.30 & 9.20 & 3.30 & 124.10 & 74.60 & 5.70 & 3.50 \\
\hline B2 & 130.20 & 1.90 & 18.44 & 7.30 & 9.30 & 3.20 & 132.00 & 72.60 & 4.90 & 3.30 \\
\hline $\begin{array}{l}\text { L.S.D. } \\
0.05\end{array}$ & 1.11 & 0.16 & N.S. & N.S. & N.S. & N.S. & N.S. & N.S. & 0.36 & 0.08 \\
\hline
\end{tabular}

B1: Inoculated

B2: Un-inoculated

Genetic factors presumably exert more control than environmental factors. Plant height is a very important morphological characteristic. Increasing the plant height can be an advantage in terms of competition with other plants in a plant community. The increasing in plant height when inoculation of faba bean seed with bacteria before planting was $4.6 \%$ compared to uninoculation in the combined analysis.

Co-inoculation with Rhizobium and Azotobacter increased seed and straw yield/fad by 16.3 and $6.1 \%$ compared to uninoculation in the combined analysis, respectively. The increasing in seed and straw yield with inoculated due to 
increased most yield components characters (number of branches/plant, number of plants $/ \mathrm{m}^{2}$, number of seeds/pod and weight of 100 seeds) compared with uninoculation. These results were concordant with those obtained by Dashadi et al. (2011), Rugheim \& Abddelgani (2012) and Alipour et al. (2013).

\section{Effect of interaction (intercropping $x$ inoculation)}

Data tabulated in Table 3 show the effect of the interaction of intercropping and inoculation for faba bean seed was significant differences in all studied characters except number of pods/plant, pod length, number of seeds/pod and weight of 100 seeds. The data of the combined analysis of the two seasons show that the highest values of most yield components were obtained by solid planting except pod length and wt. of 100-seed were obtained by in faba bean + onion and inoculation for faba bean seeds with Rhizobium and Azotobacter while the lowest values were recorded by faba bean $\mathrm{x}$ wheat (intercrop) and uninoculation. Similar results were observed by Radwan et al. (2007) and Alipour et al. (2013).

TABLE 3. Effect of interaction (cropping systems $x$ co-inoculation) on yield and yield components of faba bean during the first, second and combined analysis of two seasons.

\begin{tabular}{|c|c|c|c|c|c|c|c|c|c|c|}
\hline \multirow[t]{2}{*}{ Traits } & \multirow{2}{*}{$\begin{array}{c}\text { Plant } \\
\text { height } \\
(\mathbf{c m})\end{array}$} & \multicolumn{3}{|c|}{ No. of } & \multirow{2}{*}{$\begin{array}{c}\text { Pod } \\
\text { length } \\
(\mathrm{cm})\end{array}$} & \multirow{2}{*}{$\begin{array}{c}\text { No. of } \\
\text { seeds/ } \\
\text { pod }\end{array}$} & \multirow{2}{*}{$\begin{array}{c}\text { Wt. of } \\
\text { seeds/ } \\
\text { plant (g) }\end{array}$} & \multirow{2}{*}{$\begin{array}{l}\text { Wt. of } \\
100 \\
\text { seeds } \\
(\mathrm{g})\end{array}$} & \multicolumn{2}{|c|}{ Yield / fad } \\
\hline & & $\begin{array}{c}\text { branches/ } \\
\text { plant }\end{array}$ & $\begin{array}{c}\text { plants/ } \\
\mathbf{m}^{2}\end{array}$ & $\begin{array}{l}\text { pods/ } \\
\text { plant }\end{array}$ & & & & & $\begin{array}{c}\text { Seed } \\
(\text { ardab) }\end{array}$ & $\begin{array}{c}\text { Straw } \\
\text { (ton) }\end{array}$ \\
\hline A1B1 & 144.10 & 2.50 & 27.50 & 8.58 & 9.46 & 3.41 & 178.00 & 76.10 & 8.00 & 4.10 \\
\hline $\begin{array}{l}\text { A1B2 } \\
\end{array}$ & 137.90 & 2.38 & 28.80 & 7.96 & 9.96 & 3.38 & 182.80 & 74.38 & 7.80 & 3.90 \\
\hline A2B1 & 141.60 & 2.13 & 18.60 & 7.33 & 9.78 & 3.25 & 91.10 & 85.53 & 5.40 & 3.90 \\
\hline $\begin{array}{l}\text { A2B2 } \\
\end{array}$ & 130.90 & 2.01 & 18.80 & 7.76 & 9.68 & 3.15 & 123.30 & 81.83 & 4.70 & 3.50 \\
\hline A3B1 & 124.80 & 1.35 & 15.10 & 6.13 & 8.40 & 3.11 & 103.30 & 61.33 & 2.80 & 2.50 \\
\hline A3B2 & 122.30 & 1.23 & 16.00 & 6.31 & 8.31 & 3.04 & 90.00 & 61.15 & 2.30 & 2.40 \\
\hline $\begin{array}{l}\text { L.S.D. } \\
0.05\end{array}$ & 3.6 & 0.29 & 1.8 & N.S. & N.S. & N.S. & 15.9 & N.S. & 2.66 & 0.11 \\
\hline
\end{tabular}

A1B1: Faba bean solid x Inoculated

A1B2: Faba bean solid x Un-inoculated

A2B1: Faba bean $x$ Inoculated + onion

A2B2: Faba bean $x$ Un-inoculated + onion

A3B1: Faba bean $x$ Inoculated + wheat

A3B2: Faba bean $x$ Un-inoculated + wheat

Effect of intercropping faba bean on intercropped crops

Data presented in Table 4 showed that all studied characters of onion and wheat were significant affected by intercropping with faba bean except leaves length in second season, bulb diameter in first season, wt. of bulb in the two seasons and bulb yield/fad in the two seasons and the combined, as well as, plant height in first season and no. of spikes $/ \mathrm{m}^{2}$ in second season for wheat crops. The highest values were recorded by solid planting for both crops (onion or wheat). The reduction in bulb yield of onion was 3.0 and $4.4 \%$, while the reduction in wheat yield was 7.8 and $9.3 \%$ with or without inoculated faba bean seeds, respectively (combined analysis). Similar results were observed by AbouKeriasha et al. (2008 and 2011).

Egypt. J. Agron. 35, No. 2 (2013) 
TABLE 4 . Effect of intercropping faba bean on onion and wheat crop in the first and second seasons and combined analysis.

\begin{tabular}{|c|c|c|c|c|c|c|c|}
\hline \multirow[b]{2}{*}{$\begin{array}{l}\text { Traits } \\
\text { systems }\end{array}$} & \multicolumn{4}{|c|}{ Onion } & \multicolumn{3}{|c|}{ Wheat } \\
\hline & $\begin{array}{c}\text { Leaves } \\
\text { length } \\
(\mathrm{cm})\end{array}$ & $\begin{array}{c}\text { Bulb } \\
\text { diameter } \\
(\mathrm{cm})\end{array}$ & $\begin{array}{c}\text { Wt. } \\
\text { Bulb } \\
(\mathrm{kg})\end{array}$ & $\begin{array}{c}\text { Bulb } \\
\text { yield/fad } \\
\text { (ton) }\end{array}$ & $\begin{array}{c}\text { Plant } \\
\text { height } \\
(\mathrm{cm})\end{array}$ & $\begin{array}{c}\text { No. of } \\
\text { spikes/ } \\
\text { m }^{2}\end{array}$ & $\begin{array}{c}\text { Grain } \\
\text { yield/fad } \\
\text { (ardab) }\end{array}$ \\
\hline \multicolumn{8}{|c|}{ First season } \\
\hline $\mathbf{A 1}$ & 36.76 & 6.73 & 0.16 & 14.50 & 99.00 & 488.00 & 19.66 \\
\hline A2 & 31.66 & 6.40 & 0.17 & 14.20 & 96.60 & 474.00 & 17.80 \\
\hline A3 & 33.86 & 6.40 & 0.13 & 13.80 & 96.00 & 479.00 & 18.10 \\
\hline L.S.D. 0.05 & 3.9 & N.S. & N.S. & N.S. & N.S. & 8.4 & 1.7 \\
\hline \multicolumn{8}{|c|}{ Second season } \\
\hline A1 & 35.66 & 7.00 & 0.21 & 14.16 & 100.00 & 495.00 & 20.80 \\
\hline A2 & 35.33 & 6.30 & 0.18 & 13.53 & 95.60 & 487.00 & 19.50 \\
\hline $\mathbf{A 3}$ & 34.33 & 5.90 & 0.18 & 13.60 & 94.30 & 481.60 & 18.60 \\
\hline L.S.D. 0.05 & N.S. & 0.8 & N.S. & N.S. & 1.8 & N.S. & 1.2 \\
\hline \multicolumn{8}{|c|}{ Combined of the two seasons } \\
\hline A1 & 36.20 & 6.86 & 0.22 & 14.33 & 99.50 & 491.50 & 20.23 \\
\hline $\mathbf{A 2}$ & 33.50 & 6.36 & 0.17 & 13.90 & 96.16 & 480.50 & 18.66 \\
\hline $\mathbf{A 3}$ & 34.10 & 6.16 & 0.17 & 13.70 & 95.33 & 479.50 & 18.35 \\
\hline L.S.D. 0.05 & 2.11 & 0.4 & 0.04 & N.S. & 3.14 & 10.2 & 0.38 \\
\hline
\end{tabular}

A1: Solid

A2: Inoculated faba bean seeds

A3: Un-inoculated faba bean seeds

\section{Competitive relationships and yield advantages}

\section{Land equivalent ratio (LER)}

Data in Table 5 indicates that land equivalent ratio (LER), competitive ratio (CR) and monetary advantage index (MAI) varied considerably due to the effects of intercropping system and inoculation for faba bean seeds in the combined data of the two seasons. Their results revealed that the yield of faba bean, onion and wheat were decreased. The highest values of faba bean (0.61) were observed when intercropping with onion and inoculation faba bean seeds, while the lowest values (0.29) were observed when intercropping with wheat and uninoculation faba bean seeds. Whereas, the relative yield of onion and wheat was 0.98 and 0.95 when intercropping with inoculation faba bean seeds but when intercropping with inoculation faba bean seeds were 0.90 and 0.92 , respectively.

Land equivalent ratio (LER) values were greater than one. It could be concluded that actual productivity was higher than the expected productivity. The highest LER value (1.59) was observed when intercropping inoculation faba bean seed on onion, while the lowest value (1.2) was observed by intercropping inoculation faba bean seeds on wheat. 
TABLE 5 . Effect of intercropping and inoculation on competitive relationships and advantages of combined data.

\begin{tabular}{|c|c|c|c|c|c|c|c|c|c|c|}
\hline \multirow{3}{*}{$\begin{array}{l}\text { Traits } \\
\text { systems }\end{array}$} & \multirow{3}{*}{$\begin{array}{c}\text { Bio- } \\
\text { fertilizer }\end{array}$} & \multicolumn{3}{|c|}{ Yield } & \multicolumn{3}{|c|}{ LER } & \multicolumn{2}{|c|}{ CR } & \multirow{3}{*}{ MAI } \\
\hline & & \multirow[b]{2}{*}{$\begin{array}{l}\text { Faba } \\
\text { bean }\end{array}$} & \multicolumn{2}{|c|}{ Intercropping } & \multirow[b]{2}{*}{$\mathbf{L}_{\mathbf{F}}$} & \multirow[b]{2}{*}{$\mathbf{L}_{\mathbf{C}}$} & \multirow[b]{2}{*}{ Total } & \multirow[b]{2}{*}{$\mathbf{C R}_{\mathrm{F}}$} & \multirow[b]{2}{*}{$\mathbf{C R}_{\mathrm{C}}$} & \\
\hline & & & Onion & Wheat & & & & & & \\
\hline Solid onion & --- & --- & 14.50 & --- & --- & --- & --- & --- & --- & --- \\
\hline Solid wheat & --- & --- & --- & 19.60 & --- & --- & --- & --- & --- & --- \\
\hline \multirow{2}{*}{$\begin{array}{l}\text { Solid } \\
\text { faba bean }\end{array}$} & With & 8.80 & --- & --- & --- & --- & --- & --- & --- & --- \\
\hline & Without & 7.80 & --- & --- & --- & --- & --- & --- & --- & --- \\
\hline \multirow{2}{*}{$\begin{array}{l}\text { Faba bean + } \\
\text { onion }\end{array}$} & With & 5.40 & 14.20 & --- & 0.61 & 0.98 & 1.59 & 1.24 & 0.80 & 3636.477 \\
\hline & Without & 4.70 & 13.80 & --- & 0.60 & 0.95 & 1.55 & 1.26 & 0.79 & 3282.258 \\
\hline \multirow{2}{*}{$\begin{array}{l}\text { Faba bean }+ \\
\text { wheat }\end{array}$} & With & 2.80 & -- & 17.80 & 0.30 & 0.90 & 1.20 & 0.71 & 1.40 & 1600.590 \\
\hline & Without & 2.30 & -- & 18.10 & 0.29 & 0.92 & 1.21 & 0.52 & 1.77 & 1335.050 \\
\hline
\end{tabular}

$\mathrm{L}_{\mathrm{F}}$ : Land equivalent ratio of faba bean

$\mathrm{L}_{\mathrm{C}}$ : Land equivalent ratio of onion or wheat

$\mathrm{CR}_{\mathrm{F}}$ : Competitive ratio of faba bean

$\mathrm{CR}_{\mathrm{C}}$ : Competitive ratio of onion or wheat

\section{Competitive ratio $(C R)$}

Data on competitive ratio which expresses the exact degree of competitively. The competitive ratio (CR) of faba bean was great (1.24 and 1.26) than competitive ratio (CR) of onion when grown together, indicate that faba bean crop was more competitive than onion. This indicating the dominance of faba bean on onion. While the competitive ratio of intercropped wheat with faba bean was greater (1.4 and 1.77) than faba bean. It is indicating that dominance of wheat on faba bean. These results are agreement with those obtained by Abou-Keriasha et al. (2008).

Monetary advantage index (MAI)

Similar trend to that of LER and CR was also observed for MAI, which is an indicator of the economic feasibility of intercropping system. These values were positive due to LER was greater than one. The highest MAI values (3636.48) was observed when intercropping inoculation faba bean seed with Rhizobium and Azotobacter on onion. While the lowest values (1335.05) was observed when intercropping uninoculation faba bean seed on wheat. Similar results were observed by Fen et al. (2006), Abou-Keriasha et al. (2008) and Eskandari \& Ghainbarf (2010).

\section{Conclusion}

Intercropping faba bean on other winter crops (onion, wheat, sugar cane, sugar beet,...) are important factor which help increased productivity and decrease gap between the local production and human consumption.

The intercropping faba bean on wheat or onion resulted in shorter faba bean plants by 17.5 or $5.1 \mathrm{~cm}$ less sole, respectively. The yield components of intercropped faba bean were more decreased when intercropping with wheat and less with onion. The reduction in yield components led to decrease seed and straw yield/fad. The 
seeds and straw yields were decreased by 32.0 and $7.5 \%$ when intercropped on onion and by 68.5 and $36.4 \%$ when intercropped on wheat, respectively.

Inoculation faba bean seeds with Azotobacter had the highest values of plant height, no. of branches/plant, plants $/ \mathrm{m}^{2}$ and seeds/pod, as well as, wt. of 100 seeds and seed and straw yield/fad compared to uninoculated. The seed and straw yield were increased when planted with inoculated faba bean seed by 16.3 and $6.1 \%$ over with uninoculated, respectively.

Yield and yield components of both onion and wheat crops were decreased when intercropped with faba bean. The reduction in bulb yield was 3.0 and $4.4 \%$, while this reduction in wheat was 7.8 and $9.3 \%$ with or without inoculated faba bean seeds, respectively.

Finally, the results indicated that intercropping faba bean on onion is successful and useful which recorded the highest values of relative yield of faba bean $(0.61)$, land equivalent ratio (1.59) and monetary advantage index (3636.477) compared to faba bean - wheat (intercrop) which recorded the lowest values.

\section{References}

Abou-Keriasha, M.A., Gadallah, R.A. and Badr, M.M.A. (2008) Effect of preceding and intercropping crops on yield and yield components of wheat. Minufiya J. Agric. Res. 33 (3), $709-728$.

Abou-Keriasha, M.A., Gadallah, R.A. and El-Wakil, N.M.H. (2011) The influence of preceding crops and intercropping maize with cowpea on productivity and associated weeds. Egypt. J. Agron. 33 (1), 1 - 18.

Agricultural Statistics (2013) "Winter Crops". Agriculture Statistics and Economic Sector, Ministry of Agriculture and Land Reclamation, Egypt.

Alipour, N., Akbari, G.A., Kashini, Z.F. and Mohammadi, M. (2013) Evaluating the effects of different planting densities and inoculation with Rhizobium bacteria on morphological characteristics and yield of faba bean (c.v. Baraket). International J. of Biosciences, 3 (7), $42-48$.

Carter, J.M., Gardner, W.K. and Gibson, A.H. (1994) Improved growth and yield of faba beans (Vicia faba c.v. Fiord) by inoculation with strains of Rhizobium leguminosarum biorar. Viciae in acid soils in South-West Victoria. Australian J. Agric. Res. 94, 613 - 623. 
Dashadi, M., Khosravi, H., Moezzi, A., Nadian, H., Heidari, M. and Radjabi, R. (2011) Co - Inoculation of Rhizobium and Azotobacter on growth of faba bean under water deficit conditions. American - Eurasian J. Agric. Environ. Sci. 11 (3), 314 - 319.

Eskandari, H. and Ghanbari, A. (2010) Environmental response consumption in wheat and bean intercropping: Comparison of nutrient uptake and light interception. Notulae Scientia Biologicae, 2 (3), 100 - 103.

Fen, F., Zhang, F., Song, Y., Sur, J., Bao, X., Guo, T. and Li, L. (2006) Nitrogen fixation of faba bean (Vicia faba L.) interacting with a non - legume in two contrasting intercropping systems. Plant Soil, 283, 275 - 286.

Ghosh, P.K., Tripathi, A.K., Bandyo Padhyay, K.K. and Mann, M.C. (2009) Assessment of nutrieny competition and nutrient requirement in soybean-sorghum intercropping system. Europ. J. Agron. 31, $43-50$.

Khosravi, H. and Ramezanpour, M.R. (2004) Exploring the effect of some Rhizobium inoculants of the growth of faba bean in Mazandaran. J. Soil and Water Sci. 18 (2), 146 - 152.

Liben, M., Tadesse, T. and Assefa, A. (2001) Determination of nitrogen and phosphorus fertilizer levels in different maize - faba bean intercropping patterns in North Western Ethiopia. Seventh Eastern and Southern Africa Regional Maize Conference $11^{\text {th }}-15^{\text {th }}$ February, pp. $513-518$

Martin, M.P.L.D. and Snaydon, R.W. (1982) Intercropping barley and beans: Effect of planting pattern. EXP. Agric. 18, $139-148$.

Mohamed, Somaya Sin Elkhatin and Babiker, Hajer M. (2012) Effects of Rhizobium inoculation and urea fertilization on faba bean (Vicia faba) production in a Semi Desert Zone. Advances in Environmental Biology, 60 (2), 824 - 830.

MSTATC (1980) A Microcomputer Program of the design Management and analysis of Agronomic Research Experiments. Michigan State Univ., U.S.A.

Murinda, M.V. and Saxena, M.C. (1985) Agronomy of faba beans, lentils and chickpeas. In: Proceedings of the International Workshop on Faba Beans, Kabuli Chickpeas and Lentils in the 1980. Saxena, M.C. and S. Verma (Ed.), ICARDA, Aleppo, pp. $229-244$.

Radwan, T.E.E., Hassona, B.A., El-Khatib, Ilham I. and Kandil, B.A.A. (2007) Impact of nitrogen fixers and phosphate dissolving bacteria on faba bean under the influence of different amounts of phosphorus. Egyptian J. Biomedical Sci. 16, 13116.

Egypt. J. Agron. 35, No. 2 (2013) 
Rugheim, A.E. and Abdelgani, M.E. (2012) Effects of microbial and chemical fertilization yield and seed quality of faba bean (Vicia faba). International Food Res. J. 19 (2), $417-422$.

Snedecor, G.W. and Cochran, W.G. (1988) "Statistical Methods" $7^{\text {th }}$ ed. Iowa State Univ. Press, Ames, U.S.A.

Tuna, C. and Orak, A. (2007) The role of intercropping on yield potential of common vetch oat cultivated in pure stand and mixtures. J. Agric. Biol. Sci. 2 (2), $14-19$.

Vandermeer, J. (1989) "The Ecology of Intercropping". Cambridge University Press.

Willey, R.W. (1979) Intercropping its importance and research needs. Part 1: Competition and yield advantages (Field Crops Abst., 32, 1 - 10).

Willey, R.W. and Rao, M.R. (1980) Competitive ratio for quantifying competition between intercrops. Exp. Agric. 16, $117-125$.

Zhang, F., Shen, J., Li, L. and Liu, X. (2004) An overview of rhizosphere processes related with plant nutrition in major cropping systems in China. Plant Soil, 260, 89 - 99.

(Received 26/12/2013;

accepted $26 / 2 / 2014)$ 


\title{
تـأثير تــمـيلـل الفول البلدى مع البصل والقمح مع التلقيح بالعقدين أو بذون على إنتاجية المحاصيل الثيلاثة البهل
}

\author{
محمد أبو العيون مصطفى أبو كريشـة ، ناديـة محمد أحمد عيسى و نبيـه محمد \\ حسن الوكيل الويل \\ قسم بحوث التكثيف المحصولى ــعهد بحوث المحاصيل الحقلية ـ- مركز البحوث \\ الزر اعية - الجيزة - مصر النئ المصولي
}

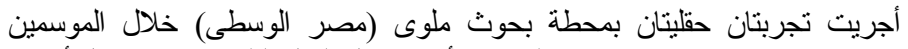

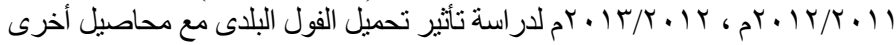

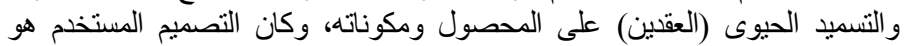

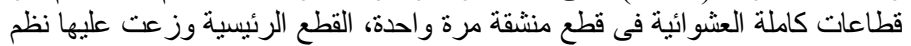

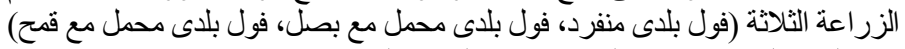
بينما القطع الثقية وز عت عليها معاملات التسميد الحيوى.

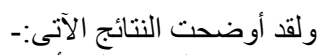

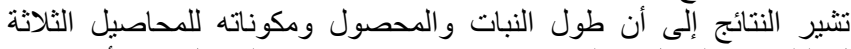

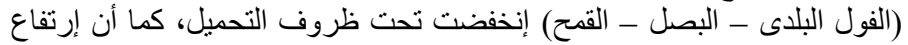

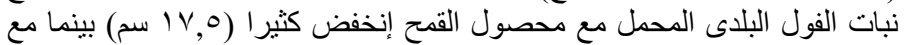

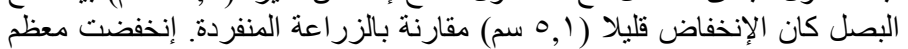

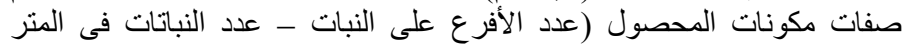

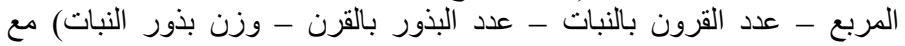

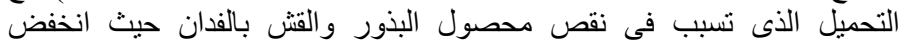

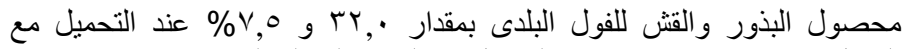

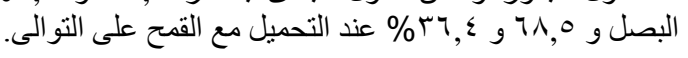

النتائج توضح أيضا أن التلقيح بالعقدين والأزوتوبكتر لبذور الفول البلدى قبل

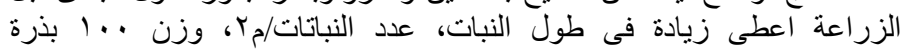

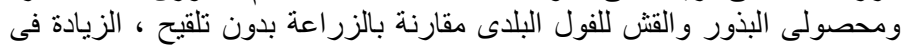

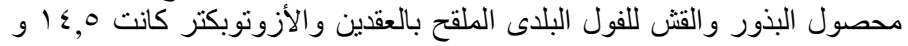

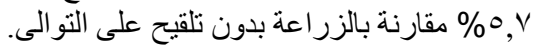

انخفض المحصول ومكونات المحصول للمحاصيل المحملة (البصل - القمح)

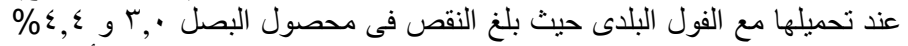

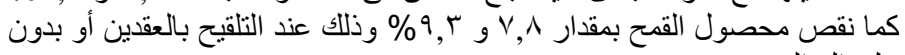

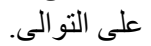

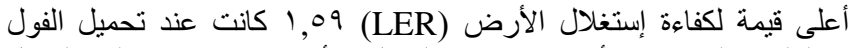

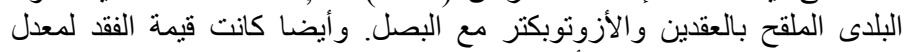

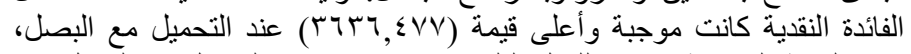

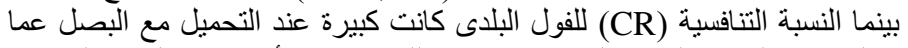
حملت مع القمح، النسبة التنافسية (CR) للقمح كانت أكبر من القيمة التنافسية 